\title{
ANALYSIS STUDY OF THE COMPARATIVE QUALITY OF PATIENT SERVICES BEFORE AND DURING COVID-19 PANDEMIC IN OUTPATIENT INSTALLATION OF SILOAM HOSPITAL TB SIMATUPANG
}

\author{
Dian Agnesa Sembiring1), Atik Nurwahyuni²), Wahyu Sulistiadi²) \\ 1)Study of Hospital Administration, Faculty of Public Health, Universitas Indonesia \\ 2)Faculty of Public Health, Universitas Indonesia
}

\begin{abstract}
Background: In the COVID-19 (Coronavirus Disease 2019) pandemic crisis that has hit Indonesia since early March 2020, urgent action is needed to overcome the situation while maintaining and improving relationships with customers so that they are still satisfied with the quality of services in hospitals, especially outpatient services. Since the COVID-19 pandemic, there has been a significant decrease in the number of inpatient visits at Siloam Hospitals TB Simatupang. This study aimed to analyze the comparison of the level of quality of patient service before and during the COVID-19 pandemic in installation of Siloam hospital TB Simatupang installation.

Subjects and Method: This was a descriptive observational study conducted at Siloam Hospitals TB Simatupang from September 2020. A sample of 88 patients was selected by purposive sampling. The data was collected by questionnaire. The operationalization of this research variable is service quality, which is measured from five dimensions, namely Tangibles, Reliability, Responsiveness, Assurance, and Empathy. The data analysis used a series of tests such as validity test, reliability test, descriptive statistics and independent sample T-test.

Results: During the COVID-19 pandemic, patients had a better perception than before the COVID19 pandemic, it can be seen from service quality (Mean=4.11), while during the COVID-19 pandemic $($ Mean $=4.25)$.

Conclusion: Quality of services provided in outpatient installations during the COVID-19 pandemic is better than before the COVID-19.

Kata Kunci: service quality, covid-19, outpatient

\section{Correspondence:}

Dian Agnesa Sembiring. Magister Program in Hospital Administration. Faculty of Public Health, University of Indonesia, Depok, West Java. Email: dianagnesa17@gmail.com
\end{abstract}

\section{BACKGROUND}

Business competition in the health industry is getting more challenging, especially the battle between hospitals. In the past, hospitals focused more on non-profit social functions. Hospitals are demanded to be oriented to health services and be able to generate profits. With the increasing number of hospitals, there will be fierce competition so that the hospital can survive. So that patients have the freedom to choose the health services they want.
The era of very high competition, especially in the service industry, managing relationships with customers is a critical factor in the company's success. If the service received exceeds consumer expectations, then the service is excellent and quality. If the service received is below consumer expectations, the service is terrible and not quality. In general, the quality of service in a hospital is based on the patient's assessment of services in the hospital, for example, the patient's relationship with nurses, doctors, and staff (Martinez, 1999).

The $7^{\text {th }}$ International Conference on Public Health

Solo, Indonesia, November 18-19, $2020 \mid 23$ https://doi.org/10.26911/the7thicph-FP.04.04 
One of the models/measuring tools developed to assess service quality based on consumer perceptions is the SERVQUAL scale (Service Quality) Berry (1988) with five dimensions, namely as follows:

1. Physical Evidence (Tangibles)

Tangibles are the company's ability to show its existence to external parties. Performance of physical facilities/infrastructure must be reliable; environmental conditions are evidence of service providers' services, such as physical facilities (buildings, warehouses, etc.), technology, tools and equipment, and employee appearance.

2. Reliability

Reliability is the company's ability to reliably and accurately deliver the promised service. The company's performance must be according to customer expectations, such as on time, equal service to all customers, an empathetic attitude, and high accuracy.

3. Responsiveness

Responsiveness is the willingness to provide and support services quickly and accurately to customers to convey information. Responsiveness services play a significant role in fulfilling wise, detailed, guiding, directing and persuasive explanations in service activities to the community.

4. Assurance

Assurance is the politeness, knowledge and ability to generate customer confidence to the company, such as credibility, communication, competence, security and decorum. The guarantee for the services provided is determined mainly by the performance or service performance, strong organizational commitment and contracts for employees who have good personality behavior.

5. Empathy

Empathy is sincere individual attention by officers to customers with an effort to understand what consumers want. Nursing personnel can show kindness by paying particular attention to each patient, paying attention to patient complaints, and each patient's needs.

Outpatient care is one of the mainstays and the largest income entry point for a hospital. However, since the COVID-19 pandemic that hit Indonesia in early March 2020, there has been a significant decrease in the number of outpatient visits at Siloam Hospitals TB Simatupang. The COVID-19 pandemic crisis (Coronavirus Disease 2019) urgently requires quick action from business people in hospitals to overcome the problem while maintaining and improving relationships with customers to remain satisfied and loyal to the quality of service that the hospital has.

On this basis, this research tries to examine more deeply the quality of service before and during the COVID-19 pandemic by conducting comparative research. The size of the service quality will be measured using the five dimensions of service quality, comprising: Tangibles, Reliability, Responsiveness, Assurance, and Empathy. Then compare the perception received consumers for the quality of service provided before and during the COVID-19 pandemic.

\section{SUBJECTS AND METHOD}

\section{Study Design}

This study used an observational research design with quantitative descriptive methods.

\section{Population and Sample}

This study's population was the total number of patients who visited the outpatient unit of Siloam Hospitals TB Simatupang in September 2020.

The study sample used purposive sampling by determining the sample based on criteria: respondents who visited the outpatient unit of Siloam TB. Simatupang has felt the conditions before and during the COVID-19 pandemic and is willing to fill out

The $7^{\text {th }}$ International Conference on Public Health

Solo, Indonesia, November 18-19, $2020 \mid 24$ https://doi.org/10.26911/the7thicph-FP.04.04 
the questionnaire given so that the number of samples obtained in 88 patients.

\section{Study Variables}

The variable measured in this study was the quality of service before and during the COVID-19 pandemic.

\section{Study Instruments}

The study was conducted using primary data, namely questionnaires, as the main data in this study.

\section{Data analysis}

The data collected will be analyzed using the independent sample T-Test, followed by a series of research instrument quality tests, namely the validity test and the reliability test.

\section{RESULTS}

Table 1 shows that female sex is more likely to be the respondent (64\%) than male gender (36\%). Then followed by the age group 21-40 years who became the most respondents as much as $74 \%$. The largest number of respondents were Diploma / S1 graduates $(60 \%)$. In the type of work, the largest number of respondents were private employees at $61 \%$. This is due to Siloam Hospitals TB Simatupang, which is in the area around offices in the TB Simatupang, Cilandak, Lebak Bulus, and surrounding areas.

More respondents became respondents, namely 50\% compared to insurance (25\%) and company guarantee (25\%). Residential distances $>5 \mathrm{~km}$ from Siloam were more respondents (72\%) compared to distances $\leq 5 \mathrm{~km}$ from Siloam (28\%). The table below illustrates the contrast of the service quality before and after the COVID19 pandemic at the outpatient installation of Siloam TB Simatupang in all dimensions.

Table 2 shows the results of data analysis using the $t$ test, namely the average incarnation dimension score during the pandemic $($ mean $=4.205 ; \mathrm{SD}=0.5926)$ higher than before the pandemic (mean= 4.051; $\mathrm{SD}=0.6017)$, and statistically significant $(\mathrm{p}=0.001)$. The mean score of the reliability dimension during the pandemic $($ mean $=4.184 ; \mathrm{SD}=0.6405)$ was higher than before the pandemic (mean= 4.050; $\mathrm{SD}=0.5785)$, and statistically significant $(\mathrm{p}=0.001)$. The mean score of the responsiveness dimension during the pandemic (mean $=4.310 ; \mathrm{SD}=0.6388)$ was higher than before the pandemic (mean= 4.185; $\mathrm{SD}=0.6062)$, and statistically significant $(\mathrm{p}=0.008)$. The mean score of the insurance dimension during the pandemic $($ mean $=4.188 ; \mathrm{SD}=0.5690)$ was higher than before the pandemic (mean= 4.188; $\mathrm{SD}=0.5690)$, and statistically significant $(\mathrm{p}=0.001)$. The mean score of the empathy dimension during the pandemic (mean= 4.239; $\mathrm{SD}=0.5943$ ) was higher than before the pandemic (mean= 4.094; $\mathrm{SD}=0.5989)$, and statistically significant $(\mathrm{p}=0.001)$.

With the results of the independent sample t-test which shows that there are significant differences in all dimensions between before and during the COVID-19 pandemic and the total average score during the COVID-19 pandemic is greater than before the COVID-19 pandemic, then if management is expected can maintain the quality of service that already exists today. 
Table 1. Sample Characteristic

\begin{tabular}{llcc}
\hline \multicolumn{1}{c}{ Variable } & \multicolumn{1}{c}{ Category } & Frequency (n) & Percentage (\%) \\
\hline Gender & Male & 32 & 36 \\
Age & Female & 56 & 64 \\
& $\leq 20$ years & 4 & 5 \\
& 21-40 years & 65 & 74 \\
education & 41-60 years & 13 & 15 \\
& Elementary-high school & 6 & 7 \\
& Diploma/S1 & 22 & 25 \\
Job & S2/S3 & 53 & 60 \\
& Not Working/Housewives & 13 & 15 \\
& Students / Students & 12 & 14 \\
& PNS/TNI/Polri & 5 & 6 \\
& Private Employees & 2 & 2 \\
& Self-employed & 54 & 61 \\
Guarantee & Professionals & 12 & 14 \\
& lawyers, etc.) & 3 & 3 \\
Personal & & \\
Distance from & Company Guarantee & 44 & 50 \\
Residence to & Insurance & 22 & 25 \\
Hospital & $>5$ km & 22 & 25 \\
\hline
\end{tabular}

Table 2. Comparison of Quality of Service Before and During Pandemic COVID-19

\begin{tabular}{lccc}
\hline \multicolumn{1}{c}{ Variable } & Mean & SD & p \\
\hline $\begin{array}{l}\text { Embodiment } \\
\text { Before Pandemic }\end{array}$ & 4,051 & 0.6017 & 0,001 \\
$\begin{array}{l}\text { During Pandemic } \\
\text { Reliability }\end{array}$ & 4,205 & 0.5926 & \\
$\begin{array}{l}\text { Before Pandemic } \\
\text { During Pandemic }\end{array}$ & 4.050 & 0.5785 & 0.001 \\
$\begin{array}{l}\text { Response } \\
\text { Before Pandemic }\end{array}$ & 4,184 & 0.6405 & \\
$\begin{array}{l}\text { During Pandemic } \\
\text { Warranty }\end{array}$ & 4,185 & 0.6062 & 0,008 \\
$\begin{array}{l}\text { Before Pandemic } \\
\text { During Pandemic }\end{array}$ & 4.310 & 0.6388 & \\
Empathy & 4,330 & 0.5690 & 0.001 \\
$\begin{array}{l}\text { Before Pandemic } \\
\text { During Pandemic }\end{array}$ & 4.094 & 0.5490 & \\
\hline
\end{tabular}




\section{DISCUSSION}

Research conducted by Fithria and Solikhawati (2015) in the two pharmaceutical installations of the Government Hospital and Private Hospital in Semarang City stated that the quality of service based on the five dimensions of SERVQUAL had not met outpatient expectations BPJS patients. The gap biggest in outpatient BPJS patients in the two hospital pharmacy installations is the dimension of responsiveness with values of -0.73 and -0.63 . The measurements that have met the expectations of outpatient BPJS patients in Sultan Agung Hospital's pharmaceutical installation are the dimensions of facilities and infrastructure with a value of 0.03 . There is a significant difference between the quality of outpatient BPJS services in the two hospital pharmacy installations on the dimensions of facilities and infrastructure (p. o,00o), and reliability (p. 0.002).

Research conducted by Noviana (2017) regarding the satisfaction level of outpatients with the service quality of the pharmaceutical installation at Pare Hospital stated that the quality of service in terms of physical facilities, reliability, responsiveness, assurance, and attention to patients participating in BPJS obtained a quality value of -0.4513 with negative interpretations and general patients, it is got a quality value of -0.2230 with a negative arrangement which means that the quality of services provided by the Outpatient Pharmacy Installation of Pare Hospital is not following patient expectations.

Another study conducted by Setiawan (2014) to see differences in satisfaction between general patients and Contribution Beneficiary National Health Insurance (JKN - PBI) patients on the quality of outpatient services at Public Health Center Nguter Sukoharjo stated that there were differences in satisfaction between general patients and recipients of National Health Insurance Beneficiaries. Contribution (JKN - PBI) for outpatient services at Public Health Center Nguter Sukoharjo. The result is significant 0.000 $(\mathrm{p}=0.000<0.05)$. To strengthen the test results of differences in employee service satisfaction between JKN-PBI patients and general patients, the mean results for JKNPBI patients are 92.61 and general patients with a mean of 70.41 . From the mean results, there is a difference of 22.2.

Research conducted by Imelda and Nahrisah (2015) related to the analysis of the level of quality of inpatient services to increase patient satisfaction at the Adam Malik General Hospital in Medan (a comparative study between general patients and BPJS patients) states that BPJS patients have known the quality of service consisting of Tangible, Reliability, Responsiveness, Assurance and Empathy have a significant effect on BPJS patient satisfaction. Whereas for non-BPJS patients, it is known that Reliability and Assurance do not affect the satisfaction of non-BPJS patients, while Tangible, Responsiveness and Empathy affect the satisfaction of Non-BPJS patients.

Based on the results of the research conducted by the researchers above, it shows that there are significant differences in all dimensions of service quality (Tangibles, Reliability, Responsiveness, Assurance, and Empathy) before and during the COVID-19 pandemic as well as the total average score during the COVID-19 pandemic. It compared to before the COVID-19 pandemic. From these results, it is hoped that management can maintain and continue to improve the quality of existing The $7^{\text {th }}$ International Conference on Public Health

Solo, Indonesia, November 18-19, $2020 \mid 27$ https://doi.org/10.26911/the7thicph-FP.04.04 
services so that they can compete in the current era of the COVID-19 pandemic.

Management also needs to pay attention to whether the quality of service is better during the COVID-19 pandemic due to the smaller number of patients compared to before the COVID-19 pandemic so that the condition of the examination room, examination conditions, conformity of services to the promised schedule, the ability of officers to handle patient complaints, the alertness of nurses in helping the examination, the attention of nurses and doctors to patients is getting better. With continuous training, the service process is expected to be consistent even though its condition is large or small.

This study's limitations are that it has not shown an analysis of patient satisfaction before and during the COVID-19 pandemic and the need for further interviews with hospital management whether additional interventions to maintain the quality of hospital services during the COVID-19 pandemic.

\section{REFERENCES}

$\overline{\text { Haryono T (2015). Pentingnya Menjaga Dan }}$ Meningkatkan Hubungan Baik Dengan Konsumen Dalam Masa Krisis. JEJAK J Ekon dan Kebijak. 3(1): 75-82.

Martínez-Fuentes C (1999). Measuring hospital service quality: a methodological study. Manag Serv Qual An Int J [Internet]. 9(4):230-40. Available from: https://www.emerald.com/insight/content/doi/10.110 8/09604529910273049/full/html

Berry LL, Parasuraman A, Zeithaml VA (1988). SERVQUAL: A multiple-item scale for measuring consumer perceptions of service quality. J Retail. 64(1):12-40.

Kumar J (2016). Patient Satisfaction in Out Patient Departments (OPDs): An Investigative Study in Government Hospitals of Haryana. 6(2).

Fithria RF, Solikhawati U (2015). Perbandingan kualitas pelayanan instalasi farmasi pasien BPJS rawat jalan rumah sakit pemerintah dan swasta Kota Semarang. Univ Wahid Hasyim Semarang. :7-15.

Noviana P (2017). Analisis Tingkat Kepuasan Pasien Rawat Jalan Terhadap Kualitas Pelayanan Instalasi Farmasi di RSUD Pare Menggunakan Metode SERVQUAL. J Wiyata. 4(2): 111-20.

Setiawan EP (2014). Perbedaan Kepuasan Antara Pasien Umum dengan Pasien Jaminan

Kesehatan Nasional Penerima Bantuan Iuran (JKN - PBI) Terhadap Kualitas Pelayanan Rawat Jalan di Public Health Center Nguter Sukoharjo. Universitas Muhammadiyah Surakarta.

Imelda S, Nahrisah E (2015). Analisis Tingkat Mutu Pelayanan Rawat Inap Dalam Upaya Peningkatan Kepuasan Pasien di RSUP Adam Malik Medan (Studi Perbandingan Antara Pasien Umum dan Pasien BPJS). J Ilm AMIK Labuhan Batu. 3(3). 